\title{
Indian Injection Technique Study: Population Characteristics and Injection Practices
}

\author{
Sanjay Kalra $\cdot$ Ambrish Mithal · Rakesh Sahay · Mathew John · \\ A. G. Unnikrishnan • Banshi Saboo · Sujoy Ghosh • Debmalya Sanyal • \\ Laurence J. Hirsch • Vandita Gupta $\cdot$ Kenneth W. Strauss (D)
}

Received: December 19, 2016 / Published online: March 13, 2017

(C) The Author(s) 2017. This article is published with open access at Springerlink.com

\begin{abstract}
Introduction: It was estimated that 3.2 million Indians with diabetes injected insulin in 2010, but little is known about the techniques used.

Methods: In 2015 we conducted an injection technique questionnaire (ITQ) survey throughout India involving 1011 patients. Indian values were compared with those from 41 other countries participating in the ITQ, known here as rest of world (ROW).
\end{abstract}

Enhanced content To view enhanced content for this article go to http://www.medengine.com/Redeem/ A2F7F0605653FD50.

S. Kalra

Bharti Hospital, Kunjpura Road, Karnal, India

A. Mithal

Medanta the Medicity, CH Baktawar Singh Road,

Sector 38, Gurgaon, Haryana, India

R. Sahay

Osmania Medical College, Turrebaz Khan Rd,

Esamiya Bazaar, Koti, Hyderabad, Telangana, India

\section{John}

Providence Endocrine \& Diabetes Specialty Centre, TC 1/2138, Near GG Hospital, Murinjapalam,

Thiruvanthapuram, Kerala, India

A. G. Unnikrishnan

Chellaram Diabetes Institute, Pune-Bangalore, NH4,

Bavdhan, Pune, Maharashtra, India
Results: Mean HbA1c was 8.6. BMI values in India were 1.5-3 units lower than in ROW depending on patient group, meaning the risk of intramuscular (IM) injections is high in India. The mean total daily dose (TDD) of insulin was lower in every category of Indian patient than in ROW, perhaps reflecting the lower BMI. Needle reuse, whether with pens or syringes, is much higher in India than ROW and so is the number of times the needle is used. The majority $(56.8 \%)$ of Indian insulin users performed only 2 injections/day as opposed to ROW where $45 \%$ of patients performed at least 4 injections/day. Indian patients inject insulin in the thighs more often than patients in ROW, a site where IM injections are more risky. Many patients do not have proper access to sharps

\section{B. Saboo}

Diacare-Diabetes Care \& Hormone Clinic, $1 \& 2$ Gandhi Park Society, Nehrunagar Cross Roads, Ambavadi, Ahmedabad, Gujarat, India

S. Ghosh

AMRI Medical Centre Kolkata, No. 97 A, Southern Avenue, Above Maruti Showroom, Opposite Lake

Stadium, Kolkata, West Bengal, India

D. Sanyal

KPC Medical College and Hospital, Raja Subodh Chandra Mullick Road, Jadavpur, Near Jadavpur Railway Station, Kolkata, West Bengal, India

L. J. Hirsch

BD Diabetes Care, 1 Becton Dr. MC 378, Franklin Lakes, New Jersey, USA 
containers or have other risk factors that could lead to blood-borne pathogen spread. More than $60 \%$ of used sharps in India go into the rubbish, with nearly $12 \%$ not even having the minimum protection of a cap.

Discussion: The shortest needles are very common in India; however, the level of needle reuse is high. Multiple daily injections therapy is not as common in India as ROW. More focus needs to be given to dwell times under the skin, reconstitution of cloudy insulins, skinfolds, and safe sharps disposal.

Keywords: Infusions; Injections; Insulin; Lipodystrophy; Lipohypertrophy; Needles; Needlestick; Subcutaneous

\section{INTRODUCTION}

The International Diabetes Federation (IDF) published statistics showing that India has the second highest number of persons with diabetes (69.1 million) than any other country except China [1]. This equates to a prevalence of $8.7 \%$ of the total adult population aged 20-79 years. In 2010 it was estimated that 3.2 million Indians with diabetes injected insulin [2], a figure that has risen significantly over the last 6 years and is projected to rise dramatically over coming decades. However, surprisingly little was known and nothing has been published about the techniques used by Indian insulin users when giving injections until the present study.

From February 2014 until June 2015 the insulin injection technique questionnaire (ITQ) survey was conducted on a worldwide basis among 13,289 patients from 425 centers in 42 countries $[3,4]$. One of the principal countries participating in the ITQ was India, with an input of 1011 patients from 20 centers representing all the major regions of the country

V. Gupta

BD Diabetes Care, BD, 6th Floor Signature Tower-B, South City I, NH 8, Gurgaon, Haryana, India

K. W. Strauss $(\square)$

BD Diabetes Care, POB 13, Erembodegem-Dorp 86, 9320 Erembodegem, Belgium

e-mail: kenneth.strauss@bd.com
(Table 1). This is one of the largest surveys of its kind ever performed in diabetes and provides landmark data on Indian injectors. The English-language versions of the questionnaire (nurse and patient forms) used in India can be found at http://www.fitter4diabetes.com. ITQ findings were used to formulate and publish new insulin delivery guidelines both on a worldwide basis [5, 6] and for India [7].

\section{METHODS}

The ITQ questionnaire consisted of an initial participant section (administered by an experienced diabetes nurse) followed by a section completed by the nurse after an injection was observed and a meticulous examination made of all injection sites.

The objectives of this questionnaire were

- To understand the epidemiologic profiles of the major insulin injection parameters

- To determine the major causes of variability in injection technique, their ranking, and their interactions

- To query the participants' perception of the injection process, the psychological barriers, and aids

Besides participant demographic information, the following key insulin injection parameters were queried by the questionnaire:

Current practice: Injection device and needle length, number of injections/day, choice of injection site, use and characteristics of skinfolds (pinch-up), needle entry angle, size of injecting zone, site rotation, disinfecting prior to injecting, dwell time of needle under the skin, site inspection by health care professional (HCP), needle reuse, sharps disposal, injection through clothing; Observed anomalies at injection sites: insulin leakage, bruising, lipoatrophy, lipohypertrophy (LH), inflammation, pain; Knowledge about injections: identity of teacher, themes covered in education, adequacy of the coverage of these themes, desire for more knowledge. Blood glucose anomalies: episodes of hypo- and hyperglycemia, hospitalizations for hypoglycemia, diabetic ketoacidosis (DKA), 
glucose variability, and unexpected hypoglycemia. Safety: needlestick injuries, risk factors for blood-borne infections, and disposal habits for used sharps.

Validation: In 2013 the 2008 version of the ITQ was reviewed and rewritten by a group of HCPs who had attended the TITAN meeting [8]. The new version, the fourth generation, was then sent to a group of 18 leading endocrinologist and diabetes educators throughout their world for their comment. Further revisions were made. Then the newest version was validated in Montreal, Canada with a group of persons with diabetes mellitus (DM) who were multilingual. A total of eight languages were represented. These patients were assessed on their understanding of each question and of the translations into various languages. Finally after further revision the 2014 ITQ was validated by the Forum for Injection Technique (FIT) board of the UK and Ireland, a group of nurse specialists who had participated in the previous ITQs.

Participating centers (Table 1) were required to understand and agree with the questions posed in the questionnaire and to recruit approximately 25 subjects/center within the allotted time frame. Subjects were not placed at any risk by the study, therapy decisions were not based on it, and no financial compensation was offered for participation. For these reasons signed informed consent was not sought.

Subject identity was kept confidential at all times and the study was conducted according to GCP and the Helsinki accords. No participant-identifying information was made available to the sponsor and participants were informed that their care would not be affected in any way by their participation. They were not put at risk in any way by the study and were not paid to participate. Ethics committee approval was therefore not generally required but was obtained whenever specifically requested by a center and/or by local regulations. All 20 participating centers in India [as in rest of world (ROW)] did so willingly and without financial incentive.

Participants were required to have used insulin for at least 6 months. In order to eliminate selection bias, subjects were recruited into the study on a sequential basis, i.e., consecutive eligible and consenting participants entering the clinic were accessioned. Injections were performed with an insulin pen or syringe or both, and participants gave verbal consent to participate. A total of 1011 Indian participants with diabetes who had both patient and nurse forms filled out were included in the ITQ database.

We recognize the importance of rural vs urban setting, availability of health care resources, and economic standing of patients in influencing outcomes. However, we elected not to capture detailed socioeconomic data in an already lengthy study. Though we do not have data on exact place of residence, we do know that the majority of centers who performed the survey in India were in urban areas and it may be necessary to extend this study to rural areas.

All results from the ITQ survey data are available in an interactive form on Tableau Public Adam Young's Profile website [9]. All differences we present are significant at a $p$ value of less than 0.5 . In a survey with such a large number of subjects $(n=1011)$ even slight differences generally reach statistical significance, often with $p$ values as low as less than 0.001 . Hence our comments are based not only on statistical tests but on the practical and clinical significance of each finding.

SPSS software was used to perform the data analysis. Descriptive statistics, frequencies, and rankings were obtained. Chi-squared analysis was performed where appropriate for contingency tables. Log linear analysis and ANOVA were used for the analysis of individual parameters, and multiple regression and correlation analysis were used for multiparametric analysis. Two-tailed tests were used in all analyses. Initially results from each of the 42 countries were analyzed independently and only when the distributions of key demographic parameters (age, sex, BMI, and duration of diabetes) were shown to be comparable were all the data pooled into an overall database.

All procedures followed were in accordance with the ethical standards of the Indian Council of Medical Research. All procedures followed were in accordance with the ethical standards of the responsible committee on human experimentation (institutional and national) and with the Helsinki Declaration of 1964, as revised in 2013. Informed consent was obtained from all patients for being included in the study. 
Table 1 Indian centers participating in ITQ study 2014-2015

\begin{tabular}{|c|c|c|}
\hline & Investigator name & Center, city \\
\hline \multicolumn{3}{|c|}{ North and Central } \\
\hline 1 & Dr. Sanjay Kalra & Bharti Hospital \& BRIDE, Karnal \\
\hline 2 & Dr. Ambrish Mithal & Mediciti, Medanta, Gurgaon \\
\hline 3 & Dr. Sujeet Jha & Max Super Specialty Hospital, Delhi \\
\hline 4 & Dr. A K Jhingan & Delhi Diabetes Research Centre, Delhi \\
\hline 5 & Dr. S K Bhattar & Regency Hospital, Kanpur \\
\hline \multicolumn{3}{|c|}{ South } \\
\hline 6 & Dr. Sahay & Dr Sahay Clinic, Hyderabad \\
\hline 7 & Dr. Prasanna Kumar & Center For Diabetes \& Endocrine Care, CDEC, Bangalore \\
\hline 8 & Dr. Srikanth & Srikanth's Diabetes Specialities Centre, Vijaywada \\
\hline 9 & Dr. Harish Kumar, Dr. Usha Menon & Amrita Institute of Medical Sciences, AIMS, Cochin \\
\hline 10 & Dr. Mathew John & Providence Endocrine \& Diabetes Specialty centre, Trivandrum \\
\hline 11 & Dr. Pneerselvam & Aruna Diabetic Clinic, Chennai \\
\hline 12 & Dr. Ajith & Sree Gokulam Medical College, Trivandrum \\
\hline \multicolumn{3}{|c|}{ West } \\
\hline 13 & Dr. UnniKrishnan & Chellaram Diabetes Institute CDI, Pune \\
\hline 14 & Dr. Benny Neglur & Prathamesh Hospital, Dombivli, Thane \\
\hline 15 & Dr. Bansi Saboo & Diabetes Care and Hormone Clinic Dia Care, Ahmedabad \\
\hline 16 & Dr. Sunil Gupta & Diabetes Care and Research Centre, DCRC, Nagpur \\
\hline 17 & Dr. Medha Oak & Oak Hospital, Dombivli, Thane \\
\hline \multicolumn{3}{|l|}{ East } \\
\hline 18 & Dr. Sujoy Ghosh & AMRI Medical Centre Kolkata \\
\hline 19 & Dr. Debmalya Sanyal & KPC Medical College and Hospital, Kolkata \\
\hline 20 & Dr. C Bhattacharya & Sun Valley Hospital, Guwahati \\
\hline
\end{tabular}

\section{RESULTS}

\section{Population Descriptors}

Table 2 gives the population statistics for the Indian participants accessioned to the study, compared side to side with the ROW data [10]. Table 3 shows the patient age breakdown and identity of the injector. Table 4 shows the characteristics of Indian participants compared to ROW. Overall $94.6 \%$ of Indian participants were adults and $56.2 \%$ were male. Regarding diabetes type, $13.6 \%$ had type 1 (T1DM), $85.9 \%$ type 2 (T2DM), and $0.5 \%$ gestational (GDM).

\section{Devices and Key Injection Practices}

Table 5 lists the injection devices used and needle reuse practices in India versus ROW. It is 
Table 2 Population demographics for Indian and ROW patients

\begin{tabular}{lllcr}
\hline & Mean India & Mean ROW & N India & $\boldsymbol{N}$ ROW \\
\hline Age & 51.1 & 52.0 & 1008 & 12,217 \\
BMI & 25.8 & 26.6 & 991 & 11,815 \\
Years with DM & 12.0 & 13.4 & 936 & 8261 \\
Age at diagnosis & 38.8 & 40.0 & 911 & 11,826 \\
Years on pills & 10.6 & 8.1 & 587 & 6020 \\
Years on insulin & 5.5 & 9.0 & 837 & 7405 \\
TDD ${ }^{\text {r regular }}$ & 29.3 & 26.6 & 208 & 1214 \\
TDD rapid analogues & 26.2 & 32.1 & 144 & 3323 \\
TDD NPH & 16.5 & 32.6 & 73 & 1061 \\
TDD basal analogues & 23.0 & 27.9 & 285 & 4424 \\
TDD premix & 34.9 & 46.5 & 545 & 1251 \\
Overall TDD & 36.9 & 50.2 & 982 & 6774 \\
HbAlc & 8.6 & 8.5 & 896 & 6767 \\
\hline
\end{tabular}

ROW (rest of world) constitutes the mean values of the 41 other ITQ participating countries combined (excluding India)

a TTD (total daily dose) of insulin is the combined total of all insulin used in 1 day in IU (international units)

Table 3 Identity of patient (or carer) who filled out the ITQ

\begin{tabular}{lrr}
\hline Patient identifier & \multicolumn{1}{c}{ \% } & \multicolumn{1}{c}{$\boldsymbol{N}$} \\
\hline Self-injecting adult (18 years old or older) & 94.6 & 839 \\
Self-injecting adolescent (13-17 years old) & 1.6 & 14 \\
Self-injecting child (<13 years old) & 1.7 & 15 \\
Parent who gives injections to my child & 2.1 & 19 \\
Missing & & 124 \\
Total & & 1011 \\
\hline
\end{tabular}

clear that syringes are much more commonly used in India than in ROW and that needle lengths are significantly different. The 4-mm needle is used more commonly in India than ROW, while the $5-\mathrm{mm}$ needle is rarely used. Over $50 \%$ of Indian patients on pen needles used the $4-\mathrm{mm}$ needle; over $50 \%$ on syringes used the 6-mm needle (data not shown). In both cases these are the shortest needles available for the respective devices. Needle reuse, whether with pens or syringes, is much higher in India than ROW and so is the number of times the needle is used (Tables 5, 6).

\section{Injections/Day and Injection Sites}

Table 7 gives the number of injections/day in both India and ROW. More than half of Indian patients performed only 2 injections/day, a far higher percentage than in ROW. The percentages of Indian patients giving 1 or 3 injections/day are similar to those for ROW. The percentages of Indian patients performing at least 4 injections/day are lower than those in ROW.

Figure 1 shows the recommended injection sites [11-15] and Table 8 shows the sites used by Indian patients and ROW. Table 9 presents percentages for specific injecting zones or combinations of zones for both India and ROW. Note that the combination of zones most commonly used are different on the bottom two rows (marked with darker shading). 
Table 4 Characteristics of Indian participants compared to ROW

\begin{tabular}{|c|c|c|c|c|c|c|c|c|}
\hline \multirow[t]{2}{*}{ Mean values } & \multicolumn{2}{|c|}{$\begin{array}{l}\text { Self-injecting adult } \\
\text { (>18 years old) }\end{array}$} & \multicolumn{2}{|c|}{$\begin{array}{l}\text { Self-injecting } \\
\text { adolescent }(13-17)\end{array}$} & \multicolumn{2}{|c|}{$\begin{array}{l}\text { Self-injecting } \\
\text { child }(<13)\end{array}$} & \multicolumn{2}{|c|}{$\begin{array}{l}\text { Child receiving } \\
\text { injections from parent }\end{array}$} \\
\hline & India & ROW & India & ROW & India & ROW & India & ROW \\
\hline Age (years) & 52.5 & 53.5 & 15.3 & 15.0 & 12.1 & 10.6 & 8.5 & 7.5 \\
\hline BMI & 26.2 & 28.4 & 18.9 & 22.0 & 15.7 & 19.1 & 16.0 & 17.5 \\
\hline HbAlc & 8.6 & 8.4 & 8.7 & 9.2 & 10.4 & 8.4 & 8.3 & 8.3 \\
\hline TDD (IU) & 36.8 & 51.0 & 44.1 & 54.8 & 34.6 & 37.9 & 24.5 & 22.7 \\
\hline Years insulin use & 5.3 & 9.4 & 5.6 & 6.0 & 3.1 & 4.4 & 3.6 & 3.6 \\
\hline
\end{tabular}

Table 5 Devices used and reuse practice: India vs ROW

\begin{tabular}{|c|c|c|}
\hline & India & ROW \\
\hline \multicolumn{3}{|l|}{ Device (\% use) } \\
\hline Syringe & 39.3 & 7.1 \\
\hline Pen & 55.0 & 88.2 \\
\hline Pump & 0.1 & 1.5 \\
\hline Pen and syringe & 5.6 & 2.3 \\
\hline \multicolumn{3}{|c|}{ Needle length used (mm) } \\
\hline 4 & 33.9 & 22.6 \\
\hline 5 & 6.2 & 38.0 \\
\hline 6 & 44.1 & 16.5 \\
\hline 8 & 15.9 & 23.0 \\
\hline \multicolumn{3}{|l|}{ Needle reuse (\%) } \\
\hline Pen & 92.5 & 53.8 \\
\hline Syringe & 80.5 & 27.9 \\
\hline \multicolumn{3}{|c|}{ Number of times pen needle reused } \\
\hline 2 & 13.9 & 33.7 \\
\hline $3-5$ & 44.2 & 38.9 \\
\hline $6-10$ & 24.5 & 14.5 \\
\hline$>10$ & 17.5 & 12.9 \\
\hline \multicolumn{3}{|c|}{ Number of times syringe reused } \\
\hline 2 & 20.9 & 45.7 \\
\hline $3-5$ & 53.5 & 37.2 \\
\hline $6-10$ & 16.1 & 8.0 \\
\hline$>10$ & 9.5 & 9.1 \\
\hline
\end{tabular}

Table 6 Estimated IM injection risk, by body site

\begin{tabular}{|l|c|c|c|c|c|}
\hline $\begin{array}{l}\text { Needle } \\
\text { Length }\end{array}$ & Combined & Thigh & Arm & Abdomen & Buttock \\
\hline $4 \mathrm{~mm}$ & $0.4 \%$ & $1.6 \%$ & $1.0 \%$ & $0.3 \%$ & $0.1 \%$ \\
\hline $5 \mathrm{~mm}$ & $1.8 \%$ & $4.7 \%$ & $3.1 \%$ & $1.1 \%$ & $0.5 \%$ \\
\hline $6 \mathrm{~mm}$ & $5.7 \%$ & $10.0 \%$ & $7.0 \%$ & $2.8 \%$ & $1.3 \%$ \\
\hline $8 \mathrm{~mm}$ & $15.3 \%$ & $25.0 \%$ & $19.5 \%$ & $9.7 \%$ & $5.5 \%$ \\
\hline $12.7 \mathrm{~mm}$ & $45.0 \%$ & $63.0 \%$ & $55.0 \%$ & $38.0 \%$ & $26.9 \%$ \\
\hline
\end{tabular}

Assumes injection straight in $\left(90^{\circ}\right)$ without pinch-up (Table adapted from Hirsch [63]). Red circle identifies situations in which the IM risk is particularly high

\section{Injecting Process}

Indian patients using pens were asked how long they left the needle under the skin after the plunger had been completely pushed down (recommendations suggest $10 \mathrm{~s}$ or more). Compliance with this rule by Indian patients was only $12.5 \%$ (Table 10 ). Table 11 summarizes the size of injection sites, skinfolds, and injection angles for India vs ROW.

Indian patients were asked to make a mock injection while their nurse observed the technique. One of the parameters evaluated was whether the patient lifted a skinfold and, if so, whether it was lifted properly and released correctly. In India $79.6 \%$ of patients lift a skinfold and $75.4 \%$ do it correctly. However, less than 
Table 7 Number of injections administered by patients, Indian vs ROW

\begin{tabular}{llllr}
\hline $\begin{array}{l}\text { Number of } \\
\text { injections/day }\end{array}$ & $\begin{array}{l}\text { India } \\
\%\end{array}$ & $\begin{array}{l}\text { ROW } \\
\%\end{array}$ & \multicolumn{1}{l}{$\begin{array}{l}\text { India } \\
\text { N }\end{array}$} & \multicolumn{1}{l}{\begin{tabular}{l} 
ROW \\
\hline 1
\end{tabular}} \\
\hline 16.1 & 16.0 & 163 & 1523 \\
2 & 56.8 & 26.0 & 574 & 2480 \\
3 & 14.2 & 13.0 & 143 & 1240 \\
4 & 10.9 & 33.7 & 110 & 3213 \\
5 & 1.6 & 7.7 & 16 & 735 \\
6 & 0.3 & 2.1 & 3 & 197 \\
$>6$ & 0.1 & 1.4 & 1 & 141 \\
Missing & & & 1 & 3760 \\
Total & 100 & 100 & 1011 & 13,289 \\
\hline
\end{tabular}

ROW (rest of world) constitutes the values from the 41 other ITQ participating countries combined (excluding India)

half release the fold appropriately (the last option in Table 12).

\section{Insulins}

Table 13 shows the breakdown of the major categories of insulin used in India compared to ROW. More than $40 \%$ of Indian patients use premixes. Considerably fewer patients in India use the newer analogues, either short-acting or basal, than in ROW.

Patients were queried about where they stored their insulin prior to opening it and $86.4 \%$ of Indian patients reported doing so in the refrigerator. After opening it, $75.0 \%$ of Indian patients continued to store it in the fridge. Of these only $63.3 \%$ let it to return to room temperature before injecting.

Indian patients using cloudy insulin $(\mathrm{NPH}$, $\mathrm{N}$, or premixed insulin) were asked if they reconstituted the insulin before injection, and $66.3 \%$ said yes. They were then asked how many times they rolled or tipped their vial or pen to reconstitute the insulin before injecting it (recommendations suggest 20 rolls or tips are necessary to completely remix crystalline insulin). Table 14 shows that over $97 \%$ of Indian

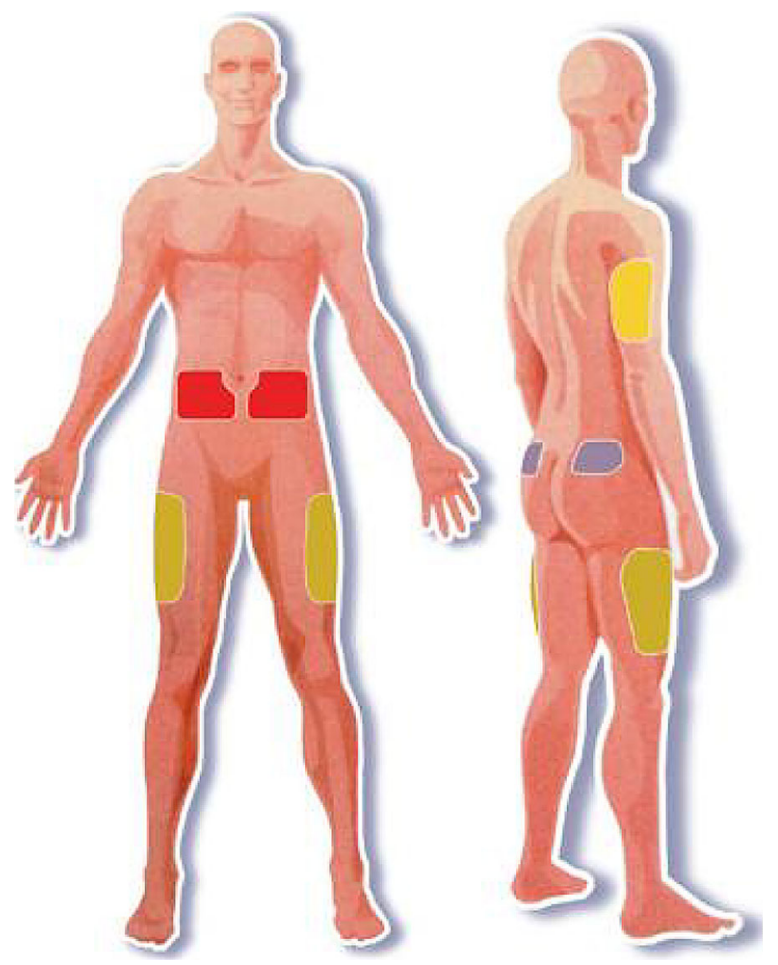

Fig. 1 Four principal insulin injection body sites (see colored patches)

Table 8 Injection sites used by Indian insulin injectors

\begin{tabular}{llrll}
\hline $\begin{array}{l}\text { Injection site } \\
\text { used }\end{array}$ & $\begin{array}{l}\text { \% } \\
\text { India }\end{array}$ & $\begin{array}{l}\text { \% } \\
\text { ROW }\end{array}$ & $\boldsymbol{N}$ India & $\boldsymbol{N}$ ROW \\
\hline Abdomen & 51.4 & 49.1 & 816 & 11,609 \\
Thigh & 32.5 & 24.9 & 515 & 5874 \\
Buttocks & 1.7 & 7.6 & 27 & 1802 \\
Arm & 14.4 & 18.4 & 229 & 4338 \\
Total & 100 & 100.0 & $1587^{\mathrm{a}}$ & $23,623^{\mathrm{a}}$ \\
\hline
\end{tabular}

a Number over 1011 for India and 13,289 for ROW (total number of patients) since many were using more than one injection site

patients using cloudy insulins only tip or roll them 10 times or less.

Patients were queried about ever skipping injections and, if so, how often and why. In India $48.2 \%$ of patients admit they skip injections and Table 15 shows the frequency. The most common reason given was "I forgot" 
Table 9 Injection sites used (alone or in combination): India vs ROW

\begin{tabular}{|c|c|c|c|c|c|}
\hline & \multicolumn{2}{|c|}{ India } & \multicolumn{3}{|l|}{ ROW } \\
\hline & $\%$ & $N$ & & $\%$ & $N$ \\
\hline Abdomen alone & 38.1 & 375 & Abdomen alone & 42.0 & 5365 \\
\hline Thigh alone & 8.3 & 82 & Thigh alone & 2.9 & 372 \\
\hline Arm alone & 4.0 & 39 & Arm alone & 2.1 & 264 \\
\hline Abdomen/thigh & 30.7 & 302 & Abdomen/thigh & 16.6 & 2125 \\
\hline Abdomen/arm & 5.3 & 52 & Abdomen/arm & 6.7 & 852 \\
\hline Thigh/arm & 4.4 & 43 & Thigh/arm & 2.8 & 358 \\
\hline Buttocks/arm & 1.1 & 11 & Abdomen/thigh/arm & 12.9 & 1648 \\
\hline Abdomen/thigh/arm & 8.0 & 79 & All 4 & 7.8 & 996 \\
\hline
\end{tabular}

Table 10 Dwell times after pen injection

\begin{tabular}{lll}
\hline Time & $\begin{array}{l}\text { \% India } \\
N=653\end{array}$ & $\begin{array}{l}\text { \% ROW } \\
N=\mathbf{8 6 7 3}\end{array}$ \\
\hline$<5 \mathrm{~s}$ & 15.7 & 18.6 \\
$5-10 \mathrm{~s}$ & 31.8 & 45.6 \\
$>10 \mathrm{~s}$ & 12.5 & 31.9 \\
"Not aware of how long" & 4.6 & 3.9 \\
\hline
\end{tabular}

Table 11 Size of injection sites, skinfolds, and injection angle: India vs ROW

\begin{tabular}{lll}
\hline & $\begin{array}{l}\text { India } \\
\text { N=759 }\end{array}$ & $\begin{array}{l}\text { ROW } \\
\boldsymbol{N}=\mathbf{8 3 9 4}\end{array}$ \\
\hline Size of injection area (ABD) & & \\
Post card & 52.6 & 57.9 \\
Playing card & 29.5 & 19.0 \\
Credit card & 14.9 & 15.4 \\
Postage stamp & 3.0 & 7.7 \\
Inject into a skinfold & 79.6 & 61.5 \\
Inject into skin at $90^{\circ}$ & 84.9 & 84.4 \\
\hline
\end{tabular}

(69.0\%). Patients were asked if they disinfected the skin before injections and $31.8 \%$ said they did. (Of vial users, $17.4 \%$ reported disinfecting the cap before drawing in their insulin.) Only
$5.4 \%$ of Indian patients injected through clothing.

\section{Needlestick Injuries}

Patients were asked if there were any persons in their surroundings who might accidentally get injured with sharps and $14.5 \%$ said yes. They were asked to identify these persons (Table 16). They were then asked if any sharps injuries had already occurred and $8.2 \%$ said yes. Finally they were asked whether any risk factors for those around them existed (Table 17). Patients were queried about how they dispose of their used sharps (Table 18) and what the "final resting place" for their collection of used needles was, i.e., where did they take the container once it was full (Table 19).

\section{DISCUSSION}

The Indian ITQ survey canvased the entire country with five centers from the North and Central regions, seven from the South, five from the West, and three from the East (Table 1). Patient demographic data (Table 2) suggest that our population was representative of both T1DM and T2DM patients who inject insulin. The fact that our patients had been living with diabetes for an average of 12 years and had been using insulin for a mean of 5.5 years suggests 
Table 12 Timing of release of skinfold

\begin{tabular}{lll}
\hline When released? & $\begin{array}{l}\text { \% India } \\
\text { N= 875 }\end{array}$ & $\begin{array}{l}\text { \% ROW } \\
\text { N=5445 }\end{array}$ \\
\hline Once the needle is in the skin & 14.9 & 18.5 \\
Once the insulin is totally injected & 38.5 & 33.5 \\
$\begin{array}{l}\text { Once the insulin is injected and } \\
\text { the needle is removed from the }\end{array}$ & 46.6 & 48.0 \\
skin & & \\
\hline
\end{tabular}

Table 13 Type of insulin used in India

\begin{tabular}{|c|c|c|c|c|}
\hline Type of Insulin & $\begin{array}{l}\% \\
\text { India }\end{array}$ & $\begin{array}{l}\% \\
\text { ROW }\end{array}$ & $N$ India & $N$ ROW \\
\hline $\begin{array}{l}\text { Short-acting human } \\
\text { ( } \mathrm{R} \text { or regular) }\end{array}$ & 15.7 & 10.1 & 194 & 1239 \\
\hline $\begin{array}{l}\text { Rapid-acting } \\
\text { analogue }\end{array}$ & 12.4 & 29.1 & 154 & 3567 \\
\hline $\mathrm{NPH}$ & 5.8 & 9.1 & 72 & 1117 \\
\hline $\begin{array}{l}\text { Long-acting } \\
\text { analogue }\end{array}$ & 23.0 & 37.3 & 285 & 4566 \\
\hline $\begin{array}{l}\text { Premix human or } \\
\text { analogue }\end{array}$ & 43.1 & 14.4 & 534 & 1758 \\
\hline Total & 100.0 & 100.0 & $1239^{\mathrm{a}}$ & 12,247 \\
\hline
\end{tabular}

that they had sufficient experience to render credible data regarding injection technique and the experience overall (Table 2). While it is disappointing that the overall HbA1c value for India was 8.6, this is in keeping with ROW averages for insulin injectors.

Our questionnaire covered all the major aspects of injections by insulin users in India, including demographics, all important injecting practices and parameters, complications of injections, and the patient's education on, feelings about, and psychological hurdles relating to injecting. Where relevant we compared Indian values to those of ROW (41 other countries).

With such a large number of subjects in this survey $(n=1011)$ even slight differences (e.g.,
Table 14 Number of times cloudy insulin tipped or rolled before injecting

\begin{tabular}{llc}
\hline Number rolls/tips & $\begin{array}{l}\text { \% India } \\
N=\mathbf{5 3 1}\end{array}$ & $\begin{array}{c}\text { \% ROW } \\
N=\mathbf{3 1 4 2}\end{array}$ \\
\hline 2 & 23.5 & 7.3 \\
3 & 15.1 & 7.3 \\
4 & 12.8 & 5.5 \\
5 & 22.8 & 16.1 \\
10 & 23.1 & 34.6 \\
15 & 2.3 & 4.4 \\
20 & 0.5 & 10.2 \\
\hline
\end{tabular}

Table 15 Frequency of skipping injections

\begin{tabular}{lcl}
\hline Frequency & $\begin{array}{c}\text { \% India } \\
\text { N= 1009 }\end{array}$ & $\begin{array}{l}\text { \% ROW } \\
\boldsymbol{N}=\mathbf{1 3 , 1 4 4}\end{array}$ \\
\hline $\begin{array}{ll}\text { Often (several times a week) } \\
\text { Sometimes (several times a } \\
\text { month) }\end{array}$ & 8.3 & 8.5 \\
$\begin{array}{l}\text { Almost never } \\
\quad \text { several times a year) }\end{array}$ & 48.5 & 35.9 \\
\hline
\end{tabular}

$1 \%$ ) between groups generally reach statistical significance, often with $p$ values as less than 0.000 . Hence our comments will focus on the clinical and practical significance of each of our findings, not on $p$ values and purely mathematical probabilities.

\section{Skin/Fat Thickness and IM Risk}

Indian BMI values are lower, in adults, adolescents, and children, compared to those in ROW (Table 4), reflecting the fact that Asians in general are at higher risk for T2DM at lower BMIs than most ethnicities in other regions of the world. Perhaps for this reason, we found that the mean TDD of insulin was lower in every category of Indian patient than in ROW (Table 4). Lower BMI values may also have contributed to the popularity of the shorter insulin needles, as Indian patients become aware of the risks of IM injections with the 
Table 16 Persons in household at risk of sharps injury

\begin{tabular}{lll}
\hline Who? & $\begin{array}{l}\text { \% India } \\
N=\mathbf{2 4 5}\end{array}$ & $\begin{array}{l}\text { \% ROW } \\
\boldsymbol{N}=\mathbf{1 5 7 6}\end{array}$ \\
\hline Children & 33.5 & 23.4 \\
$\begin{array}{l}\text { Other family members (e.g., } \\
\text { spouse) }\end{array}$ & 35.8 & 39.5 \\
$\begin{array}{l}\text { Nurse or other professional } \\
\text { House keeper or rubbish collector }\end{array}$ & 27.3 & 8.3 \\
\hline
\end{tabular}

Table 17 Risk factors for sharps injury

\begin{tabular}{lll}
\hline Reason & $\begin{array}{c}\text { \% India } \\
N=362\end{array}$ & $\begin{array}{l}\text { \% ROW } \\
N=\mathbf{2 6 8 4}\end{array}$ \\
\hline $\begin{array}{l}\text { I don't use devices that prevent } \\
\text { injuries to others (safety }\end{array}$ & 19.9 & 28.4 \\
$\begin{array}{l}\text { devices) } \\
\begin{array}{l}\text { I don't have appropriate disposal } \\
\text { containers for my used sharps }\end{array}\end{array}$ & \\
$\begin{array}{l}\text { Used sharps are sometimes left in } \\
\text { places where others might get } \\
\text { stuck }\end{array}$ & 43.8 & 25.9 \\
$\begin{array}{l}\text { I'm positive for hepatitis or } \\
\text { another blood-borne illness }\end{array}$ & 4.4 & 4.5 \\
\hline
\end{tabular}

longer needles, especially in the presence of their lower BMI.

Syringe use continues to be common in India compared to ROW, but use of the shortest needles is very common in India regardless of whether pens or syringes are used. The 4- and 6-mm needles are the most popular lengths (Table 5). When we cross-matched these findings to injecting device we found that the 4-mm needle (shortest in the pen line) was the most commonly used by pen users and the $6-\mathrm{mm}$ needle (shortest in syringes) was the most commonly used by syringe users. Hence the message of the superiority of the shortest needle seems to have been heeded amongst professionals and patients in India.

Comparison of previous worldwide ITQs show that needle length over the last 5-6 years
Table 18 Disposal habits for used sharps

\begin{tabular}{|c|c|c|}
\hline Where are they disposed? & $\begin{array}{l}\% \text { India } \\
N=1001\end{array}$ & $\begin{array}{l}\% \text { ROW } \\
N=12,785\end{array}$ \\
\hline $\begin{array}{l}\text { Into a container specially made } \\
\text { for used sharps }\end{array}$ & 9.8 & 20.7 \\
\hline $\begin{array}{l}\text { Into a home container such as } \\
\text { an empty bottle }\end{array}$ & 20.0 & 23.0 \\
\hline $\begin{array}{l}\text { Into the rubbish with the cap } \\
\text { on }\end{array}$ & 57.0 & 48.1 \\
\hline $\begin{array}{l}\text { Into the rubbish without } \\
\text { recapping }\end{array}$ & 11.8 & 6.9 \\
\hline $\begin{array}{l}\text { I clip off the needle and it stays } \\
\text { in the clipper }\end{array}$ & 1.4 & 1.3 \\
\hline
\end{tabular}

Table 19 Ultimate disposal of sharps waste

\begin{tabular}{lll}
\hline What do you do with the waste? & $\begin{array}{l}\text { \% India } \\
\text { N=583 }\end{array}$ & $\begin{array}{l}\text { \% ROW } \\
\text { N= 6183 }\end{array}$ \\
\hline Put it into the rubbish & 60.9 & 40.3 \\
Take it to a pharmacist & 1.2 & 12.8 \\
Take it to a doctor's office & 0.7 & 6.3 \\
Take it to a laboratory & 1.4 & 0.4 \\
Take it to the hospital or clinic & 6.2 & 22.1 \\
Take it to a local deposit or & 20.4 & 11.0 \\
collection service & & \\
None of the above & 9.3 & 7.1 \\
\hline
\end{tabular}

has shifted dramatically, away from the $8 \mathrm{~mm}$ and towards the 4 and $5 \mathrm{~mm}$. This follows a trend towards shorter needles that began 2 decades ago. But in the last 5-6 years, a seachange has occurred with a much faster conversion to $4 \mathrm{~mm}$ than seen with other needle length changes. Currently just less than $30 \%$ of ROW patients use 4 and $8 \mathrm{~mm}$, respectively $[3,4]$. Just over $20 \%$ of ROW use the 5 and $6 \mathrm{~mm}$, respectively. There is considerable variability, however, country to country worldwide, but it appears that India is now ahead of the curve. However we are still concerned that considerable percentages of Indian patients 
continue to use the $8-\mathrm{mm}$ needle in high-risk sites (e.g., in the limbs, especially in males).

Recent studies indicate that skin thickness at insulin injection sites in a varied population of adults with diabetes differs minimally by patient characteristics, including BMI (e.g., obese patients have similar skin thickness as normal and thin patients) [16]. However the same study showed that fat thickness (SC space) varied widely from one individual to another on the basis of gender, BMI, and injection zone of the body. It highlighted the risk of IM injections and showed that they were lowest with 4-mm needles. A study recently published in India confirms these findings [17].

Table 6, adapted from another publication [18], shows the risk of IM injections as a function of needle length. The red circle identifies situations in which the IM risk is particularly high, i.e., injections with 6- and 8-mm needles in the limbs (arms and thighs). Comparative analysis of the worldwide ITQ data [3] revealed that the 4-mm needle was associated with lower BMI, fewer years on insulin, younger age, lower total daily doses (TDD) of insulin, more fingersticks/day, less hyperglycemia and hospitalization for hypoglycemia, less needle reuse, and less LH (all difference with $p<0.05$ by multivariate analysis).

\section{Needle Length}

The 4-mm/32G pen needles were shown to provide equivalent glycemic control (HbA1c) to $8-\mathrm{mm} / 31 \mathrm{G}$ and $12.7-\mathrm{mm} / 29 \mathrm{G}$ pen needles in a large, prospective randomized controlled crossover study of obese patients taking large insulin doses, with two separate arms (4 vs $8 \mathrm{~mm}$ and 4 vs $12.7 \mathrm{~mm}$ ) [19]. There was no increase in backflow or skin leakage with the 4-mm needles. Additionally patients reported less injection pain with the 4-mm needles. There is no evidence to date of additional leakage of insulin, $\mathrm{LH}$, or pain nor of poorer diabetes control or other complications in patients using 4-, 5-, or 6-mm needles [19-25].

Additional studies have recently been performed using the 4-mm needle with identical results. Miwa et al. [26] compared 4-mm/32G with $6-\mathrm{mm} / 32 \mathrm{G}$ needles and showed equivalent safety and efficacy results. The $4-\mathrm{mm}$ needle was judged by Japanese patients to be less painful and easier to use. Nagai et al. [27] compared 4-mm/32G to 5-mm/33G (tapered) needles and found similar results. Hirose et al. [28] performed PK/PD studies which showed bioequivalent maximum concentration and area under the curve for the $4-\mathrm{mm} / 32 \mathrm{G}$ needle relative to the $6-\mathrm{mm} / 32 \mathrm{G}$ and $8-\mathrm{mm} / 31 \mathrm{G}$ needles. A PK/ PD crossover study using the euglycemic clamp in both normal-weight and obese subjects, healthy adults showed equivalent insulin uptake and action for insulin lispro, injected one day with a 5-mm needle and another day with an 8-mm needle [29].

Birkebaek et al. [30] compared the 4-mm with the 6-mm pen needle in lean subjects, both children and adults, with diabetes. The 4-mm needle led to fewer IM injections with equivalent levels of leakage compared to the 6-mm needle. The probability of IM injection with the $6 \mathrm{~mm}$ vs the $4 \mathrm{~mm}$ was considerably higher when comparing percentages in adults and was dramatically higher in children and adolescents. Hirsch et al. [31] have shown equivalence between 4-, 5-, and 8-mm pen needles in regards to glucose control, with no difference between obese and non-obese subjects.

Lo Presti et al. [32] studied the skin and SC thickness at various injecting sites in children and adolescents with diabetes (ages 2-17) and concluded that the safest injecting alternative for all ages is the 4-mm needle. A 4-mm needle is long enough to penetrate the skin but sufficiently short to avoid reaching the muscle in the vast majority of children. However, all pediatric groups have values at the lower range of skin plus SC thickness which are below the threshold of $4 \mathrm{~mm}$. These findings show that in very young patients injections may be IM when given perpendicularly without a skinfold, even with 4-mm needles.

Hofman et al. [33] have done similar studies using the $5-\mathrm{mm}$ needle. They found that $5-\mathrm{mm}$ needles gave equivalent glucose control to 8-mm ones in both children and adults, and no substantial back flow or leakage was seen from 
$5 \mathrm{~mm}$ compared to $8 \mathrm{~mm}$ in doses up to $60 \mathrm{IU}$. Children prefer the $5-\mathrm{mm}$ to longer needles and generally have less pain with $5 \mathrm{~mm}$. HbA1c improvements on the $5-\mathrm{mm}$ needle are sometimes seen and are probably a result of fewer IM injections. Hirsch et al. [34] have shown equivalence between 4-, 5-, and 8-mm pen needles in regards to glucose control, with no difference between obese and non-obese subjects.

Strock et al. [35] performed a subgroup analysis of a large study comparing $4-\mathrm{mm} / 32 \mathrm{G}$ pen needles with $8-\mathrm{mm} / 31 \mathrm{G}$ and $12.7-\mathrm{mm} /$ $29 \mathrm{G}$ ones in obese subjects, among those taking relatively high doses of glargine ( $>40 \mathrm{IU})$. No significant differences in glucose control (as measured by HbA1c), number of hypo- or hyperglycemic events, or insulin leakage were seen in obese subjects $\left(B M I \geq 30 \mathrm{~kg} / \mathrm{m}^{2}\right.$ [2]) amongst the three needle lengths. The 4-mm needle was judged to be less painful, easier to insert, easier to use, and less anxiety-provoking than the other two lengths (all at $p<0.05$ ).

In a crossover trial involving obese adults with $\mathrm{DM}$, Ignaut and $\mathrm{Fu}$ [36] compared the 5 - $\mathrm{mm}$ to the $8-\mathrm{mm}$ pen needle. They found minimal leakage overall with no difference between needle lengths, no difference by injection volume (20 and $60 \mathrm{IU}$ compared), and no difference in bruising, bleeding, or pain between the needle lengths. They concluded that the 5-mm needle is acceptable for obese patients at low and high insulin volumes.

In a crossover trial involving obese adults $\left(\mathrm{BMI} \geq 30 \mathrm{~kg} / \mathrm{m}^{2}\right.$ ) with DM, Kreugel et al. [37] compared the $5-\mathrm{mm}$ to the $8-\mathrm{mm}$ pen needle. No within-group changes were observed using three different integrated measures of glucose control: HbA1C, serum fructosamine, and 1,5-anhydroglucitol. Furthermore, there were no differences in hypoglycemic events, bruising, or pain. The authors concluded that the $5-\mathrm{mm}$ needle may be used safely in obese patients. Several other authors [19, 31, 34] have shown equivalence between 4-, 5-, and 8-mm pen needles in regards to glucose control, with no difference between obese and non-obese subjects.

\section{Needle Reuse}

Despite the fact that India is ahead of the curve in using the shortest needles, there is a disturbingly high rate of needle reuse with both syringes and pens (Table 5). There are many possible reasons for this, including expense and convenience. Indian patients often have to pay for their needles and, when faced with tight expenses, they may choose to reuse them. It may also be possible that patients are unaware of the association between needle reuse and the presence of LH.

Vardar and Kizilci [38] identified, by logistic regression analysis, three independent risk factors for LH: duration of insulin use, with longer use associated with more LH $(p=0.001)$; site rotation, with a failure to rotate associated with higher LH risk $(p=0.004)$; changing needles, with needle reuse also associated with LH $(p=0.004)$. An earlier study [39] identified similar risk factors.

In a recent Spanish study, Blanco [40] showed a significant correlation between the presence of $\mathrm{LH}$ (in $52 \%$ of T2DM and $72 \%$ of T1DM) and the reuse of needles $(p<0.05)$, and a trend to greater frequency of LH with higher number of uses of the needle. The relationship was greatest when the needle was used more than five times. Of the patients in whom LH was found, $61 \%$ reported needle reuse. Of those who reused, $70 \%$ had $\mathrm{LH}$ (with the figure $84 \%$ in DM1). Of those who did not reuse, $57 \%$ had LH.

A similar observational study in four large Chinese cities reported an overall prevalence of LH of $53 \%$. About $95 \%$ of patients reuse needles in China, and rates did not differ between those with and without LH. Patients with LH had increased BMI, took more injections daily, and reused their needles nearly twice as many times (all $p<0.001$ ). By regression analysis, insulin dose $/ \mathrm{kg}, \mathrm{BMI}$, and needle reuse frequency are significantly associated with LH (all $p \leq 0.02$ ) [41].

As in India, the principal reasons patients in ROW reuse needles are convenience and cost [42]. The Indian guidelines [7] state clearly that "Healthcare professionals should create awareness in patients regarding the potential adverse effects of needle reuse, and discourage this 
practice" and admonish patients to "Never reuse needles, syringes or lancets as there is a high risk of transmission of blood-borne pathogens (HIV and hepatitis)."

A Russian study [43] showed that injection pain was greater with reuse, presumably from dulling of the needle tip. The authors cultured less bacteria from the tips of needles that had been used only once compared to reused needles, and they found inflammatory changes (skin redness) only at injection sites of patients who had reused needles. They did not report the occurrence of any skin or SC tissue infections, however. Similar observations have been reported by others for plastic insulin syringe use [44, 45].

Puder et al. [46] tested the pain of needle reuse in 270 injections and found that pain intensity and unpleasantness do not increase with repeated injections using the same needles in people with diabetes $(p=0.1$ and 0.96 , respectively) and in volunteers ( $p=0.63$ and 0.92). The authors concluded that using pen needles up to five times does not lead to needle tip deformity and does not increase pain or unpleasantness. Furthermore, needle reuse could help save money for health care systems.

After sifting the pros and cons of the above studies, it appears that needle reuse, particularly reuse frequency, is associated with the development of LH.

The majority $(56.8 \%)$ of Indian insulin users performed only 2 injections/day as opposed to ROW where $45 \%$ of patients performed at least 4 injections/day. This may reflect the fact that Indian injectors had been using insulin for only 5.5 years on average, while ROW injectors had been using it for on average 9.0 years (Table 3); or it may mean that intensive therapy with multiple daily injections (MDI) is still not common in India. The frequent use of premixes in India and the comparative lower use of analogues compared to ROW (Table 13) support the latter hypothesis.

Indian patients inject insulin in the thighs more often than patients in ROW and this is a site where IM injections are more risky (especially given the lower BMI of Indian patients). Arm use, however, is comparatively less common in India than in ROW, and use of the buttocks is exceedingly rare (Tables 8,9 ).

\section{Absorption by Site and IM Injections}

Absorption characteristics change depending on the type of insulin given. Abdominal site subcutaneous (SQ) injection of soluble rapid-acting ("regular") insulin results in 29\% lower postprandial plasma glucose concentrations than thigh site injections [11, 47]. This effect is due to more rapid absorption from the abdomen. Furthermore, the use of inappropriate sites and techniques may modify insulin absorption parameters so that maximum glucose load does not match peak insulin effect. This can lead to unexpected hyperglycemia as well as a greater risk of nocturnal hypoglycemia. [48-54]. Analogues can be given at any injection site with similar absorption and action (PK-PD), but human insulins (regular, NPH) vary a great deal-absorption is fastest from the abdomen and slowest from the buttocks.

Both human insulins and analogues have different absorption profiles when administered into muscle. In 1988 Frid et al. [55] showed that human soluble insulin was absorbed faster from muscle compared to fat tissue, especially when the muscles were exercised. Vaag et al. [56] showed the same for NPH insulins in 1990. Thow et al. [57] have shown that significantly higher amounts of infused glucose were required during a glucose clamp to maintain euglycemia from IM injections than from SC ones.

In contrast the rapid-acting insulin analogue lispro seems to have the same speed of absorption from fat tissue and resting muscle tissue [58]. There are no published studies for modern long-acting analogues, but clinical experience and a case report [59] make it probable that long-acting analogues are absorbed faster from muscle compared to fat tissue.

Hence IM injections, especially into working muscle, can distort absorption of possibly all of the insulins and thus decouple maximum glucose load from peak insulin activity. This can lead to poor glycemic control, including excessive glycemic variability. When this happens IM 
injections may lead to unexplained hypoglycemia according to a number of studies $[55,60,61]$.

Patients may not be aware that they are injecting IM. Thow and Home [62] have shown that IM injections are no more painful than SC. It is likely that many patients have been unknowingly injecting IM for years-especially with the newer, thinner needles.

Hirsch et al. [63] have recently shown that BMI, gender, and body site are the most critical factors impacting SC fat thickness. Women have nearly $5 \mathrm{~mm}$ more fat than men given the same BMI. Hence, men are at much greater risk for IM injections than women (2-4 times). The lower the $\mathrm{BMI}$ is, the greater the IM risk is. Body site is critical. Injections in the thigh have 2- to 4 -fold greater IM risk at any length needle than injections in the abdomen. Abdomen and thigh are, of course, the most common sites used.

There is a general paucity of studies regarding insulin absorption from deep or superficial parts of subcutaneous fat tissue. However Frid and Lindén [12] showed no difference in absorption of soluble human insulin from deep compared to superficial injection in patients with T1DM. A more recent study has also suggested that the depth of insulin injection (shallow versus deep SC tissue) does not affect the absorption of insulin [64].

\section{Proper Use of Pens}

More than a quarter of Indian patients report insulin dripping from the tip of their pen needle after injecting and one out of five report leakage of insulin from their injection sites (data not shown). Both these sources of insulin loss may be the result of not leaving the pen needle under the skin for the requisite time (a full $10 \mathrm{~s}$ ). Only $12.5 \%$ of Indian patients do so (Table 10).

After pushing the thumb button completely in, patients should slowly count to ten before removing the needle in order to get the complete dose and to prevent leakage of insulin [21, 65-69]. Counting higher than ten may be necessary for larger doses. Counting merely to five may be acceptable for low doses. Patients can find the ideal time for themselves by trial and error, using insulin leakage as a guide.
Pens and cartridges should never be shared between patients because of the risk that biological material from one patient could be drawn into the cartridge and then injected into a subsequent person [70, 71]. Pen needles should be disposed of right after use instead of being left attached. This prevents the entry of air into the cartridge as well as the leakage of insulin. Leakage can affect dose accuracy [21, 67, 71-73]. Pen needles should be used only once [44, 74-80].

\section{Proper Use of Syringes}

India is one of the regions of the world where numbers of patients continue to use syringes as their primary device. In India where pens are used for many home injections, syringes are still used predominantly in hospitals. Often hospital insulin syringes are reused, i.e., a patient is assigned a syringe which is used to give all his/ her insulin injections during the hospitalization. This increases the risk of blood-borne pathogen transmission since HCPs usually give these injections, recapping the needle between them. Needlestick injuries occur, and the most frequent provoking event is needle recapping.

Whether in the hospital or at home, there is no rationale for using syringes with detachable needles for injecting insulin. Permanently attached needle syringes provide better dose accuracy, reduced cannula diameters, and smaller dead space. They also allow patients to mix insulins if needed. Currently there are no syringes with a needle less than $6 \mathrm{~mm}$ in length because of incompatibility with some vial stoppers [81].

\section{Reconstituting Cloudy Insulins}

A major educational challenge for Indian patients using cloudy insulins (NPH alone or in premixes) is to tip or roll their vial or pen a sufficient number of times for the insulin to go completely back into solution. Failure to do this can lead to uneven concentrations of insulin which can provoke hyper- or hypoglycemia. Only $0.5 \%$ of Indian users of such insulins were compliant with the recommendation to tip or roll 20 times.

German studies [65, 82-85] have revealed the extent of inadequate suspension of cloudy 
insulins. Some longer-acting insulins have a predetermined ratio of either crystalline insulin and rapid-acting soluble insulin or crystalline insulin and solvent. The crystalline element must be resuspended before each injection; however, patients may not know how best to do this. We believe this is the case in India. Inadequate resuspension of NPH insulin before pen injection is common among Indian patients treated with insulin.

Jehle et al. [86] showed that NPH resuspension was only achieved after mixing (tipping or rolling) 20 times immediately before injection. Patients, however, find this procedure annoying. The authors found that fewer than one in ten did it. Brown et al. [87] found similar results and concluded that significant inappropriate dosing resulted from inadequate resuspension.

Kaiser et al. [88] found that the amount of mixing needed to resuspend NPH varies according to manufacturer. Cartridges with the heaviest and highest number (three) of "bullets" inside took less mixing. However cartridges have only one or two lighter glass "bullets" inside and these take much more effort to resuspend. If resuspension is not done properly doses of NPH are well below what is anticipated by the patient. Kaiser et al. found that all cartridges performed well when used according to the instructions for use, i.e., when mixed 20 times.

\section{Insulin Storage}

Indian patients were asked where they stored their insulin before opening it and nearly nine out of ten reported doing so in the refrigerator. After opening it, three out of four Indian patients continued to store it in the fridge, probably reflecting the fact that ambient temperatures in India are often over $30^{\circ}$. However only $63.3 \%$ of those storing insulin in the fridge let it warm up to room temperature before injecting it (a possible cause of injection pain).

\section{Skinfolds}

Pinching up the skin is a method that has been shown by computerized tomography (CT) scan and ultrasonography to increase the chance of subcutaneous injection. Nevertheless, even a pinch-up may not protect children from intramuscular injections if they use 8-mm needles (which are the shortest currently available in syringes). Polak et al. [89] have shown, however, that a lifted skinfold does not always eliminate the risk of an IM injection, especially in younger thinner children and when using these longer needles. Intramuscular injection occurred more frequently in boys and correlated with lower percentile of BMI and shorter distances from skin surface to muscle fascia, with or without a skinfold. A second study [90] found that the use of 8-mm needles in 50 thin to normal children, all of whom used a pinch-up, significantly reduced but by no means eliminated the risk of intramuscular injections. Thus needles even shorter than $8 \mathrm{~mm}$ must be used in children, which calls into question the use of syringes in this population.

We observed whether Indian patients lifted a skinfold and, if so, whether it was lifted correctly and released appropriately. In India more than three-quarters of patients lift a skinfold and, of these, three-quarters do it correctly. However, fewer than half of Indian patients release the fold appropriately (Table 12). Figure 2 shows correct (left) and incorrect (right) ways of performing the skinfold [47].

\section{Safety Needles}

Management of used sharps in India is a major challenge according to our study. There are comparatively higher percentages of children and housekeepers exposed to used sharps in India than in ROW (Table 16). Many patients do not have proper access to sharps containers or have other risk factors that could lead to blood-borne pathogen spread (Table 17). Far too many used sharps go into the rubbish in India, either with a cap on or without (Tables 18, 19).

\section{Disposal of Injecting Material}

India has its own regulations regarding the disposal of contaminated biologic waste. Of note in this study is the fact that more than $60 \%$ of used sharps go into the rubbish, with nearly $12 \%$ not even having the minimum protection of a cap. These 

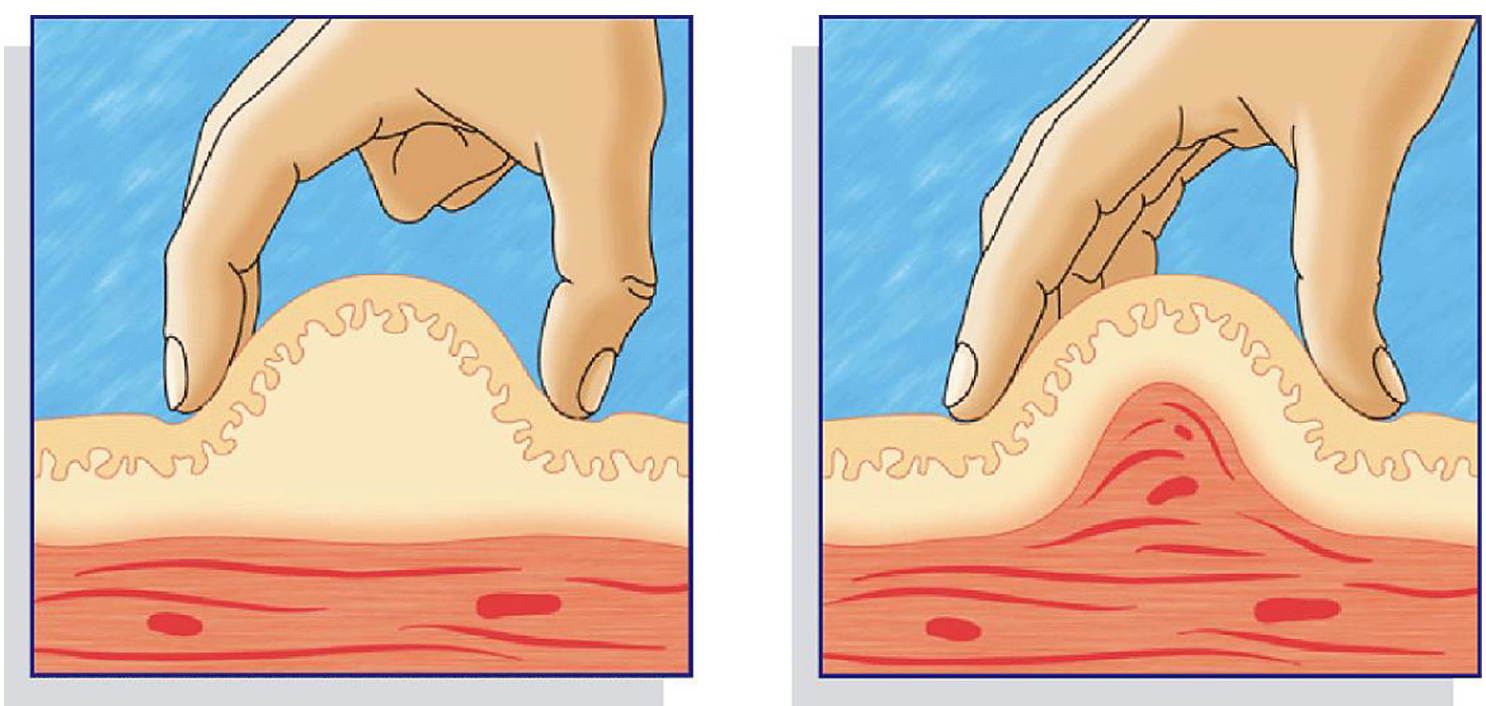

Fig. 2 Correct (left) and incorrect (right) technique for lifting a skinfold

"naked needles" pose an imminent threat to anyone who comes near the rubbish, e.g., family members, house cleaners, rubbish collectors, or those operating incinerators or frequenting dumps.

\section{CONCLUSION}

The first Indian insulin injection technique recommendations were published in Indian Journal of Endocrinology \& Metabolism, November 2012 issue. Addenda were published in the November 2013 and November 2014 issues of that journal. The latest version of these recommendations were published in 2015 [7]. That version provides the following guidelines for insulin needles and injection hygiene:

\section{Children and adolescents}

- Children and adolescents should use a 4-mm needle with pens and the shortest needles available (currently $6 \mathrm{~mm}$ ) with syringes.

- No clinical reason exists to recommend needles longer than $6 \mathrm{~mm}$ in children and adolescents.

- In children who are slim, when injecting into the limbs, a skinfold is required: Especially when using a 5- or 6-mm needle.

- An injection angled at $45^{\circ}$ with a $6-\mathrm{mm}$ needle can be used instead of a skinfold.
- If only an 8-mm needle is available, then they should lift a skinfold and/or inject at $45^{\circ}$.

- Injection into the arms needs third-party assistance and a lifted skinfold for needle length more than $5 \mathrm{~mm}$.

Adults

- Adults including obese patients can use a 4-mm needle with pens and 6-mm-long needles with syringes.

- Adults do not require the lifting of a skinfold, particularly for 4-mm and 5-mm needles.

- Shorter needles should be given in adults at a $90^{\circ}$ angle to the skin surface.

- An injection into the limbs or a slim abdomen warrants a skinfold with needles longer than $5 \mathrm{~mm}$.

- No clinical reason is available for recommending needles longer than $6 \mathrm{~mm}$ in adults.

- Patients already using needles $\geq 8 \mathrm{~mm}$ should move to a shorter needle or lift a skinfold and/or inject at $45^{\circ}$ in order to avoid injecting into muscle.

\section{Needle/syringe hygiene}

Needle reuse causes the blunting and bending of the needle tip, increasing the risk of

- Bleeding, bruising, or scarring

- Dosage inaccuracy 
- Lipohypertrophy

Healthcare professionals should create awareness in patients regarding the potential adverse effects of needle reuse, and discourage this practice.

Injection storage: recommendations

- Store insulin in use at room temperature $\left(15-25^{\circ} \mathrm{C}\right)$ and discard 30 days after initial use or follow manufacturer's instructions.

- Currently unused vials/refill cartridges (meant to be used in future) should be refrigerated.

- Never freeze (frozen insulin should be thrown away).

- Storage recommendations specific to the insulin formulation according to the manufacturer's instructions (package insert) are to be checked before use.

- When storing prefilled insulin syringes, store them with the needle pointing up.

- Never use insulin beyond the expiration date stamped on the vial, pen, or cartridge that is supplied by the drug manufacturer.

- Avoid extremes of temperature such as

- Direct sunlight

- Kitchen

- Closed cars

- The top of a radiator

- The top of a television

- Green houses

Safe disposal of injection devices

- Awareness of local regulations should be created among patients and healthcare professionals. Legal and societal consequences of nonadherence should be reviewed.

- Patients should be educated about correct disposal right from injection initiation and this should be reinforced throughout the therapy.

- The patient's family members, especially children, and service professionals (rubbish collectors and cleaners) should be made aware of potential risks.

- Sharp materials should never be disposed of in public trash bins or areas.
- Empty pen devices can be disposed in household refuse bins.

We believe the Indian ITQ data support and reinforce the above recommendations. Every diabetes center in India should be familiar with the ITQ results and should be scrupulous in following the official Indian insulin injection recommendations.

This paper will be followed by another one entitled Indian Injection Technique Study: Injecting Complications, Education and the Health Care Professional [91].

\section{ACKNOWLEDGEMENTS}

No funding or sponsorship was received for this study or publication of this article.

All named authors meet the International Committee of Medical Journal Editors (ICMJE) criteria for authorship for this manuscript, take responsibility for the integrity of the work as a whole, and have given final approval for the version to be published.

Our sincerest thanks go to the 20 Indian centers (Table 1) with their 72 health care professionals and 1011 patients for performing the ITQ study. They have given an invaluable gift to the world of Indian diabetes.

Disclosures. Kenneth W. Strauss is an employee of $\mathrm{BD}$, a manufacturer of injecting devices.

Laurence J. Hirsch is an employee of $\mathrm{BD}$, a manufacturer of injecting devices.

Vandita Gupta is an employee of $\mathrm{BD}$, a manufacturer of injecting devices.

Sanjay Kalra, Ambrish Mithal, Rakesh Sahay, Mathew John, AG Unnikrishnan, Banshi Saboo, Sujoy Ghosh, and Debmalya Sanyal have nothing to disclose.

Compliance with Ethics guidelines. All procedures followed were in accordance with the ethical standards of the Indian Council of Medical Research, the ethical standards of the 
responsible committee on human experimentation (institutional and national), and with the Helsinki Declaration of 1964, as revised in 2013. Informed consent was obtained from all patients for being included in the study.

Data Availability. All results from the ITQ survey data are available in an interactive form on Tableau Public Adam Young's Profile website [9].

Open Access. This article is distributed under the terms of the Creative Commons Attribution-NonCommercial 4.0 International License (http://creativecommons.org/licenses/ by-nc/4.0/), which permits any noncommercial use, distribution, and reproduction in any medium, provided you give appropriate credit to the original author(s) and the source, provide a link to the Creative Commons license, and indicate if changes were made.

\section{REFERENCES}

1. International Diabetes Federation. India. 2015. http://www.idf.org/membership/sea/india. Accessed 4 Mar 2017.

2. Prasad R. Innovate for diabetes in India. http://blogs. novonordisk.com/graduates/2010/10/27/innovatefor-diabetes-in-india/. Accessed 4 Mar 2017.

3. Frid AH, Hirsch LJ, Menchior AR, Morel DR, Strauss KW. Worldwide injection technique questionnaire study: population parameters and injection practices. Mayo Clinic Proc. 2016;91(9):1212-1223. http://www.mayoclinicproceedings.org/article/S00256196(16)30322-6/fulltext. Accessed 4 Mar 2017.

4. Frid AH, Hirsch LJ, Menchior AR, Morel DR, Strauss KW. Worldwide injection technique questionnaire study: injecting complications and role of the professional. Mayo Clinic Proc. 2016;91(9):1224-1230. http://www.mayoclinicproceedings.org/article/S00 25-6196(16)30326-3/fulltext. Accessed 4 Mar 2017.

5. Frid AH, Kreugel G, Grassi G, et al. New insulin delivery recommendations. Mayo Clinic Proc. 2016;91(9):1231-1255. http://www.mayoclinic proceedings.org/article/S0025-6196(16)30321-4/full text. Accessed 4 Mar 2017.

6. Drake MT, Smith SS. Optimizing insulin delivery in patients with diabetes mellitus: still room for improvement. Mayo Clinic Proc. 2016;91(9): 1155-1157. http://www.mayoclinicproceedings. org/article/S0025-6196(16)30410-4/fulltext. Accessed 4 Mar 2017.

7. Tandon N, Kalra S, Balhara YS, et al. Forum for Injection Technique (FIT), India: The Indian recommendations 2.0, for best practice in insulin injection technique, 2015. Indian J Endocr Metab. 2015;19(3):317-331.

8. Frid A, Hirsch L, Gaspar R, et al. New injection recommendations for patients with diabetes. Diabetes Metab. 2010;36(2):S3-18.

9. ITQ survey data. Tableau Public Adam Young's Profile website: http://tabsoft.co/23V6ofi. Accessed 8 June 2016.

10. The worldwide data is labelled ROW (Rest Of World) and constitutes the mean values of the 41 other ITQ participating countries combined (excluding India).

11. Bantle JP, Neal L, Frankamp LM. Effects of the anatomical region used for insulin injections on glycaemia in type 1 diabetes subjects. Diabetes Care. 1993;16:1592-7.

12. Frid A, Lindén B. Intraregional differences in the absorption of unmodified insulin from the abdominal wall. Diabet Med. 1992;9:236-9.

13. Koivisto VA, Felig P. Alterations in insulin absorption and in blood glucose control associated with varying insulin injection sites in diabetic patients. Ann Intern Med. 1980;92:59-61.

14. Annersten M, Willman A. Performing subcutaneous injections: a literature review. Worldviews Evidence Based Nurs. 2005;2:122-30.

15. Vidal M, Colungo $\mathrm{C}$, Jansà $\mathrm{M}$. Actualización sobre técnicas y sistemas de administración de la insulina (I) [Update on insulin administration techniques and devices (I)]. Av Diabetol. 2008;24:175-90.

16. Gibney MA, Arce CH, Byron KJ, Hirsch LJ. Skin and subcutaneous adipose layer thickness in adults with diabetes at sites used for insulin injections: implications for needle length recommendations. Curr Med Res Opin. 2010;26:1519-30.

17. Jain SM, Pandey K, Lahoti A, Rao PK. Evaluation of skin and subcutaneous tissue thickness at insulin injection sites in Indian, insulin naïve, type- 2 diabetic adult population. Indian J Endocrinol Metab. 2013;17(5):864-70.

18. Hirsch L, Byron K, Gibney M. Intramuscular risk at insulin injection sites-measurement of the distance from skin to muscle and rationale for 
shorter-length needles for subcutaneous insulin therapy. Diabetes Technol Ther. 2014;16(12):867-73.

19. Bergenstal RM, Strock ES, Peremislov D, Gibney MA, Parvu V, Hirsch LJ. Safety and efficacy of insulin therapy delivered via a $4 \mathrm{~mm}$ pen needle in obese patients with diabetes. Mayo Clin Proc. 2015;90(3):329-38.

20. Birkebaek N, Solvig J, Hansen B, Jorgensen C, Smedegaard J, Christiansen J. A $4 \mathrm{~mm}$ needle reduces the risk of intramuscular injections without increasing backflow to skin surface in lean diabetic children and adults. Diabetes Care. 2008;22:e65.

21. Jamal R, Ross SA, Parkes JL, Pardo S, Ginsberg BH. Role of injection technique in use of insulin pens: prospective evaluation of a 31-gauge, $8 \mathrm{~mm}$ insulin pen needle. Endocr Pract. 1999;5:245-50.

22. Kreugel G, Keers JC, Jongbloed A, Verweij-Gjaltema $\mathrm{AH}$, Wolffenbuttel BHR. The influence of needle length on glycemic control and patient preference in obese diabetic patients. Diabetes. 2009;58:A117.

23. Schwartz S, Hassman D, Shelmet J, et al. A multicenter, open-label, randomized, two-period crossover trial comparing glycemic control, satisfaction, and preference achieved with a 31 gauge $\times 6 \mathrm{~mm}$ needle versus a 29 gauge $\times 12.7 \mathrm{~mm}$ needle in obese patients with diabetes mellitus. Clin Ther. 2004;26:1663-78.

24. Kreugel G, Beijer HJM, Kerstens MN, ter Maaten JC, Sluiter WJ, Boot BS. Influence of needle size for SC insulin administration on metabolic control and patient acceptance. Eur Diabetes Nurs. 2007;4:1-5.

25. Van Doorn LG, Alberda A, Lytzen L. Insulin leakage and pain perception with NovoFine $6 \mathrm{~mm}$ and NovoFine $12 \mathrm{~mm}$ needle lengths in patients with type 1 or type 2 diabetes. Diabet Med. 1998;1:S50.

26. Miwa T, Itoh R, Kobayashi T, et al. Comparison of the effects of a new 32-gauge $\times 4$-mm pen needle and a 32-gauge $\times 6$-mm pen needle on glycemic control, safety, and patient ratings in Japanese adults with diabetes. Diabetes Technol Ther. 2012;14(12):1084-90.

27. Nagai Y, Ohshige T, Arai K, Kobayashi H, Sada Y, Ohmori S. Comparison between shorter straight and thinner microtapered insulin injection needles. Diabetes Technol Ther. 2013;15(7):550-5.

28. Hirose T, Ogihara T, Tozaka S, Kanderian S, Watada $H$. Identification and comparison of insulin pharmacokinetics injected with a new 4-mm needle vs 6- and 8-mm needles accounting for endogenous insulin and C-peptide secretion kinetics in non-diabetic adult males. J Diabetes Investig. 2013;4(3):287-96.

29. de la Peña A, Yeo KP, Linnebjerg H, et al. Subcutaneous injection depth does not affect the pharmacokinetics or glucodynamics of insulin lispro in normal weight or healthy obese subjects. J Diabetes Sci Technol. 2015;9:1-7.

30. Birkebaek NH, Solvig J, Hansen B, Jorgensen C, Smedegaard J, Christiansen JS. A 4-mm needle reduces the risk of intramuscular injections without increasing backflow to skin surface in lean diabetic children and adults. Diabetes Care. 2008;31(9):e65.

31. Hirsch LJ, Gibney MA, Li L, Bérubé J. Glycemic control, reported pain and leakage with a $4 \mathrm{~mm} \times 32 \mathrm{G}$ pen needle in obese and non-obese adults with diabetes: a post hoc analysis. Curr Med Res Opin. 2012;28(8):1305-11.

32. Lo Presti D, Ingegnosi C, Strauss K. Skin and subcutaneous thickness at injecting sites in children with diabetes: ultrasound findings and recommendations for giving injection. Pediatr Diabetes. 2012;13(7):525-33.

33. Hofman PL, Derraik JG, Pinto TE, et al. Defining the ideal injection techniques when using 5-mm needles in children and adults. Diab Care. 2010;33(9):1940-4.

34. Hirsch LJ, Gibney MA, Albanese J, et al. Comparative glycemic control, safety and patient ratings for a new $4 \mathrm{~mm} \times 32 \mathrm{G}$ insulin pen needle in adults with diabetes. Curr Med Res Opin. 2010;26(6):1531-41.

35. Strock E, et al. Glycemic control, pain and leakage with $4 \mathrm{~mm}$ vs larger pen needles in obese patients treated with lantus or higher insulin doses: prespecified subgroup analyses. In: Poster 997-P. EASD, Barcelona, Spain. 2013.

36. Ignaut $\mathrm{D}, \mathrm{Fu} \mathrm{H}$. Comparison of insulin diluent leakage postinjection using two different needle lengths and injection volumes in obese patients with type 1 or type 2 diabetes mellitus. J Diabetes Sci Technol. 2012;6:389-93.

37. Kreugel G, Keers JC, Kerstens MN, Wolffenbuttel $\mathrm{BH}$. Randomized trial on the influence of the length of two insulin pen needles on glycemic control and patient preference in obese patients with diabetes. Diabetes Technol Ther. 2011;13(7):737-41.

38. Vardar B, Kizilci S. Incidence of lipohypertrophy in diabetic patients and a study of influencing factors. Diabetes Res Clin Pract. 2007;77:231-6.

39. Saez-de Ibarra L, Gallego F. Factors related to lipohypertrophy in insulin-treated diabetic patients: 
role of educational intervention. Pract Diab Int. 1998;15:9-11.

40. Blanco M, Hernández MT, Strauss KW, Amaya M. Prevalence and risk factors of lipohypertrophy in insulin-injecting patients with diabetes. Diabetes Metab. 2013;39(5):445-53.

41. Hirsch L, Ji L, Sun Z, et al. Lipohypertrophyprevalence, risk factors and clinical characteristics of insulin-requiring patients in China. DTT. 2015;17(Suppl 1):A57-8.

42. De Coninck C, Frid A, Gaspar R, et al. Results and analysis of the 2008-2009 insulin injection technique questionnaire survey. J Diabetes. 2010;2(3):168-79.

43. Misnikova I, Dreval A, Gubkina V, Rusanova E. The risk of repeated use of insulin pen needles in patients with diabetes mellitus. J Diabetology. 2011;1:1-5.

44. Schuler G, Pelz K, Kerp L. Is the reuse of needles for insulin injection systems associated with a higher risk of cutaneous complications? Diabetes Res Clin Pract. 1992;16:209-12.

45. Thomas DR, Fischer RG, Nicholas WC, Beghe C, Hatten KW, Thomas JN. Disposable insulin syringe reuse and aseptic practices in diabetic patients. J Gen Intern Med. 1989;4:97-100.

46. Puder J, Atar M, Muller B, Pavan M, Keller U. Using insulin pen needles up to five times does not affect needle tip shape nor increase pain intensity. Diabetes Res Clin Pract. 2005;67:119-23.

47. Strauss K. Insulin injection techniques. Pract Diabetes Int. 1998;15:181-4.

48. Galloway J, Spradlin C, Nelson R, Wentworth S, Davidson J, Swarner J. Factors influencing the absorption, serum insulin concentration, and blood glucose responses after injections of regular insulin and various insulin mixtures. Diabetes Care. 1981;4:366-76.

49. Sindelka G, Heinemann L, Berger M, Frenck W, Chantelau E. Effect of insulin concentration, subcutaneous fat thickness and skin temperature on subcutaneous insulin absorption in healthy subjects. Diabetologia. 1994;37:377-80.

50. Henriksen JE, Djurhuus MS, Vaag A, et al. Impact of injection sites for soluble insulin on glycaemic control in Type 1 (insulin-dependent) diabetic patients treated with a multiple insulin injection regimen. Diabetologia. 1993;36:752-8.

51. Henriksen J, Vaag A, Ramsgaard Hansen I, Lauritzen M, Djurhuus M, Beck-Nielsen H. Absorption of NPH (Isophane) insulin in resting diabetic patients: evidence for subcutaneous injection in the thigh as the preferred site. Diabet Med. 1991;8:453-7.

52. Koivisto V, Felig P. Alterations in insulin absorption and in blood glucose control associated with varying insulin injection sites in diabetic patients. Ann Intern Med. 1989;92:59-61.

53. De Meijer PH, Lutterman JA, van Lier HJ, van't Laar A. The variability of the absorption of subcutaneously injected insulin: effect of injection technique and relation with brittleness. Diabet Med. 1990;7:499-505.

54. Berger M, Cüppers HJ, Hegner H, Jörgens V, Berchtold P. Absorption kinetics and biologic effects of subcutaneously injected insulin preparations. Diabetes Care. 1982;2:77-91.

55. Frid A, Gunnarson R, Guntner P, Linde P. Effects of accidental intramuscular injection on insulin absorption in IDDM. Diabetes Care. 1988;11:41-5.

56. Vaag A, Handberg A, Lauritzen M, Henriksen JE, Pedersen KD, Beck-Nielsen H. Variation in absorption of NPH insulin due to intramuscular injection. Diabetes Care. 1990;13(1):74-6.

57. Thow J, Johnson A, Fulcher G, Home P. Different absorption of Isophane (NPH) Insulin from subcutaneous and intramuscular sites suggests a need to reassess recommended insulin injection technique. Diabet Med. 1990;7(3):600-2.

58. Rave K, Heise T, Weyer C, et al. Intramuscular versus subcutaneous injection of soluble and lispro insulins: comparison of metabolic effects in healthy subjects. Diabet Med. 1998;15:747-51.

59. Karges B, Boehm BO, Karges W. Early hypoglycemia after accidental intramuscular injection of insulin glargine. Diabet Med. 2005;22:1444-5.

60. Karges B, Boehm BO, Karges W. Early hypoglycaemia after accidental intramuscular injection of insulin glargine. Diabetes Med. 2005;22(10):1444-5.

61. Spraul M, Chantelau E, Koumoulidou J, Berger M. Subcutaneous or nonsubcutaneous injection of insulin. Diabetes Care. 1988;11:733-6.

62. Thow J, Home P. Insulin Injection Technique. BMJ. 1990;301:3-4.

63. Hirsch L, Byron K, Gibney M. Intramuscular risk at insulin injection sites-measurement of the distance from skin to muscle and rationale for shorter-length needles for subcutaneous insulin therapy. Diabetes Technol Ther. 2014;16(12):867-73.

64. de la Peña A, Ma X, Reddy S, Ovalle F, Bergenstal RM, Jackson JA. Application of PK/PD modeling 
and simulation to dosing regimen optimization of high-dose human regular U-500 insulin. J Diabetes Sci Technol. 2014;8:821-9.

65. King L. Subcutaneous insulin injection technique. Nurs Stand. 2003;17:45-52.

66. Ginsberg BH, Parkes JL, Sparacino C. The kinetics of insulin administration by insulin pens. Horm Metab Res. 1994;26:584-7.

67. Annersten M, Frid A. Insulin pens dribble from the tip of the needle after injection. Pract Diab Int. 2000;17:109-11.

68. Rissler J, Jørgensen C, Rye Hansen M, Hansen NA. Evaluation of the injection force dynamics of a modified prefilled insulin pen. Expert Opin Pharmacother. 2008;9:2217-22.

69. Broadway CA. Prevention of insulin leakage after subcutaneous injection. Diabetes Educator. 1991;17:90.

70. Le Floch JP, Herbreteau C, Lange F, Perlemuter L. Biologic material in needles and cartridges after insulin injection with a pen in diabetic patients. Diabetes Care. 1998;21:1502-4.

71. Bärtsch U, Comtesse C, Wetekam B. Insulin pens for treatment of diabetes (article in German). Ther Umsch. 2006;63:398-404.

72. Byetta Pen User Manual. Eli Lilly and Company; 2007.

73. Chantelau E, Heinemann L, Ross D. Air bubbles in insulin pens. Lancet. 1989;334:387-8.

74. Strauss K, De Gols H, Letondeur C, Matyjaszczyk M, Frid A. The second injection technique event (SITE), May 2000, Barcelona, Spain. Pract Diab Int. 2002;19:17-21.

75. Strauss K. Insulin injection techniques: report from the 1st International Insulin Injection Technique Workshop, Strasbourg, France-June 1997. Pract Diab Int. 1998;15:16-20.

76. Danish Nurses Organization. Evidence-based clinical guidelines for injection of insulin for adults with diabetes mellitus, 2nd ed. 2006. English version available athttp://docplayer.net/2966550-Evidencebased-clinicalguidelines-for-injection-of-insulin-foradults-with-diabetes-mellitus.html. Accessed 4 Mar 2017.

77. Association for Diabetescare Professionals (EADV). Guideline: the administration of insulin with the insulin pen. 2008. http://www.google.co.in/url?sa= $\mathrm{t} \& \mathrm{rct}=\mathrm{j} \& \mathrm{q}=\&$ esrc $=\mathrm{s} \&$ source $=$ web $\& \mathrm{~cd}=1 \& \mathrm{ved}=0 \mathrm{ahU}$ KEwjdgd3ZqMPSAhXKr48KHcWZDAUQFggbMAA \&url=http\%3A\%2F\%2Fwww.eadv.nl\%2Fmodule\%
2F1530\%2F196\%2FGuideline-The-administrationof-insulin-with-the-insulin-pen.pdf\&usg=AFQjCNE FHElByntR2GlsmvfxTJULMipgyQ\&cad=rja. Accessed 4 Mar 2017.

78. Chantelau E, Lee DM, Hemmann DM, Zipfel U, Echterhoff S. What makes insulin injections painful? Br Med J. 1991;303:26-7.

79. Maljaars C. Scherpe studie naalden voor eenmalig gebruik [Sharp study needles for single use]. Diabetes Levery. 2002;4:36-37.

80. Torrance T. An unexpected hazard of insulin injection. Pract Diabetes Int. 2002;19:63.

81. Caffrey RM. Diabetes under control: are all syringes created equal? Am J Nurs. 2003;103:46-9.

82. Jehle PM, Micheler C, Jehle DR, Breitig D, Boehm BO. Inadequate suspension of neutral protamine Hagendorn (NPH) insulin in pens. Lancet. 1999;354:1604-7.

83. Brown A, Steel JM, Duncan C, Duncun A, McBain AM. An assessment of the adequacy of suspension of insulin in pen injectors. Diab Med. 2004;21:604-8.

84. Nath C. Mixing insulin: shake, rattle or roll? Nursing. 2002;32:10.

85. Springs MH. Shake, rattle, or roll? "Challenging traditional insulin injection practices". Am J Nurs. 1999;99:14.

86. Jehle PM, Micheler C, Jehle DR, Breitig D, Boehm BO. Inadequate suspension of neutral protamine Hagendorn (NPH) insulin in pens. Lancet. 1999;354(9190):1604-7.

87. Brown A, Steel JM, Duncan C, Duncan A, McBain AM. An assessment of the adequacy of suspension of insulin in pen injectors. Diabet Med. 2004;21(6):604-8.

88. Kaiser P, Maxeiner S, Weise A, et al. Assessment of the mixing efficiency of neutral protamine Hagedorn cartridges. J Diabetes Sci Technol. 2010;4(3):652-7.

89. Polak M, Beregszaszi M, Belarbi N, et al. Subcutaneous or intra-muscular injections of insulin in children: are we injecting where we think we are? Diabetes Care. 1996;19(12):1434-6.

90. Tubiana-Rufi N, Belarbi N, Du Pasquier-Fediaevsky $\mathrm{L}$, et al. Reduction of the risk of intra-muscular insulin injection with the $8 \mathrm{~mm}$ length needles in thin diabetic children. Diabetologia 1998;41:A247.

91. Kalra S, Mithal A, Sahay R, et al. Indian Injection Technique Study: Injecting Complications, Education, and the Health Care Professional. Diabetes Ther 2017. doi:10.1007/s13300-017-0244-9. 